\title{
Quantitative LAMP and PCR Detection of Salmonella in Chicken Samples Collected from Local Markets around Pathum Thani Province, Thailand
}

\author{
Virun Vichaibun and Panan Kanchanaphum \\ Biochemistry Unit, Department of Biomedical Science, Faculty of Science, Rangsit University, Pathum Thani 12000, Thailand \\ Correspondence should be addressed to Panan Kanchanaphum; panan.k@rsu.ac.th
}

Received 15 April 2020; Revised 8 June 2020; Accepted 23 June 2020; Published 10 July 2020

Academic Editor: Jaime Yanez

Copyright (c) 2020 Virun Vichaibun and Panan Kanchanaphum. This is an open access article distributed under the Creative Commons Attribution License, which permits unrestricted use, distribution, and reproduction in any medium, provided the original work is properly cited.

\begin{abstract}
Salmonella is a bacterium that infects people when they consume contaminated food or liquids. To prevent humans from becoming ill, it is useful to have an efficient method of detecting Salmonella before the disease is passed on through the food chain. In this research, the efficiency of Salmonella detection was compared using the following four methods: conventional loop-mediated isothermal amplification (LAMP), PCR, quantitative LAMP (qLAMP), and qPCR. The artificial infection of chicken samples started with incubating of $10 \mathrm{~mL}$ of $10^{8} \mathrm{CFU}$ of $S$. typhimurium for $6 \mathrm{hr}$. and enriching for $2 \mathrm{hr}$. to represent real contamination of the samples. The results show that the sensitivity of Salmonella DNA detection in PCR, qPCR, LAMP, and qLAMP were $50 \mathrm{ng}, 5 \mathrm{ng}, 50 \mathrm{pg}$, and and $500 \mathrm{fg}$, respectively. Thirty samples of $10 \mathrm{~g}$ chicken were collected from 10 markets in Pathum Thani, Thailand; then, the infection was detected. The conventional LAMP, qLAMP, and qPCR methods detected Salmonella in all the chicken samples. However, the conventional PCR method detected Salmonella infection in only eight of the samples. Overall, the qLAMP method had the highest sensitivity of Salmonella DNA detection.
\end{abstract}

\section{Introduction}

Salmonellosis is a major foodborne infectious disease occurring worldwide, which is caused by the Gram-negative zoonotic pathogen, Salmonella [1]. Salmonella is a member of the Enterobacteriaceae family, which has been divided into the following two species: S. enterica and S. bongori. S. enterica has been further divided into six subspecies that include over 2,500 serotypes [2]. Almost all Salmonella outbreaks have been broadly ascribed across multiple food categories, and many people have become infected by consuming contaminated food originating from animals (such as eggs, beef, poultry, and milk) [3]. The symptoms of patients diagnosed with typhoid fever, caused by Salmonella enterica serovar Typhimurium, are similar to other illnesses such as Leptospirosis and Streptococcus pneumoniae infection [4]. Powerful and more efficient methods of detecting Salmonella are still required.
The conventional method of detecting and identifying Salmonella is a microbiological procedure, which requires multiple subculture steps followed by biochemical and serological testing. The method is time consuming (5 to 7 days) and very labor intensive. Molecular methods such as PCR and quantitative PCR (qPCR) [5] have been employed in Salmonella detection due to their specificity, sensitivity, and rapidity, [6-8]. Many reports showed Salmonella contamination in raw food especially in chicken was detected by PCR $[9,10]$. However, the PCR and qPCR methods require sophisticated instruments and are time consuming. Fortunately, an innovative technique has been developed to negate these issues.

Loop-mediated isothermal amplification (LAMP) is a method of amplifying DNA under isothermal conditions. LAMP has been used in place of PCR because it provides high specificity, sensitivity, and rapidity. PCR consists of four specific primers based on six specific sequences applied to the 
DNA target and takes about one hour for the reaction time at $60^{\circ} \mathrm{C}-65^{\circ} \mathrm{C}$ for $45-60 \mathrm{~min}$ [11]. The method is more practical for microorganism detection because complicated instruments are unnecessary. Many publications in food and nutrition reported for the LAMP application such as [12] detected pork meat contamination in Halal food using LAMP.

The aim of this research is to compare the efficiency of LAMP, PCR, qualitative PCR (qPCR), and qualitative LAMP (qLAMP) by detecting Salmonella on chicken samples collected from markets around Pathum Thani province in Thailand.

\section{Materials and Methods}

2.1. Bacterial Strain and Culture Conditions. Salmonella enterica subsp. enterica serovar Typhimurium ATCC23566 was used in this study. The non-Salmonella strains belonged to the Escherichia, Bacillus, Klebsilla, Shigella, and Enterobacter genera. All the bacterial cultures were obtained from the Department of Microbiology, Faculty of Science, Rangsit University. For the cultivation, Salmonella was subcultured on xylose lysine deoxycholate agar media (XLD; Merck) and incubated at $37^{\circ} \mathrm{C}$ overnight $(16 \mathrm{hr})$. The nonSalmonella strains were sub cultured on Luria-Bertani agar plate ( $10 \mathrm{~g}$ tryptone; $5 \mathrm{~g}$ yeast extract, $10 \mathrm{~g} \mathrm{NaCl} ; 15 \mathrm{~g}$ agar; and $\mathrm{H}_{2} \mathrm{O}$ to $1,000 \mathrm{~mL}$ ) and incubated at $37^{\circ} \mathrm{C}$ overnight. The culture was used for DNA extraction using the GF-1 Bacterial DNA extraction kit (Vivantis, Malaysia) and measuring the concentration of DNA by using NanoDrop 2000c Spectophotometer (Thermo Scientific).

2.2. Primer Design for LAMP and PCR. A set of two pairs of primers, comprising of two inner primers (FIP and BIP) and two outer primers (F3 and $\mathrm{B} 3$ ) that could recognize six sequences of the Salmonella invasion gene (invA) were designed for the LAMP reaction (GenBank Accession Number M90846) [13]. To compare the efficiency of the detection methods, the F3 and B3 outer primers were used for the PCR. The nucleotide sequences of each primer are shown in Table 1.

2.3. LAMP and qLAMP Reaction. All the LAMP reactions were performed in $25 \mu \mathrm{L}$ of $1 \mathrm{x}$ Bst DNA polymerase buffer containing $5 \mathrm{mM} \mathrm{MgSO}_{4}, 400 \mathrm{mM}$ betaine (Sigma), $1.2 \mathrm{mM}$ dNTPs, $0.8 \mu \mathrm{MF} 3$ and B3 primers, $2 \mu \mathrm{M}$ FIP and BIP primers, $8 \mathrm{U}$ Bst DNA polymerase (New England Biolabs), and $10 \mathrm{ng}$ of each DNA extract as a template. The reactions were incubated at $65^{\circ} \mathrm{C}$ for $45 \mathrm{~min}$, which was followed by enzyme inactivation at $80^{\circ} \mathrm{C}$ for $5 \mathrm{~min}$. qLAMP amplification was performed by adding $0.5 \mu \mathrm{L}$ of SYBR green I dye (Invitrogen, Carlsbad, CA) to the normal LAMP reaction.

2.4. PCR and qPCR Reactions. To compare the detection efficiency, a PCR assay targeting the Salmonella invA gene was performed in parallel with LAMP primer, as shown in Table 1 . In addition, SYBR green I dye was used to enhance the specificity in the qPCR reaction. The PCR amplification reaction contained 1x Taq DNA polymerase buffer, $1.2 \mathrm{mM}$ dNTPs, $0.8 \mu \mathrm{MF} 3$ and B3 primers and $8 \mathrm{U}$ Taq DNA polymerase (New England Biolabs), and $5 \mathrm{ng}$ of each DNA extract as a template in a final volume of $25 \mu \mathrm{L}$. The cycling conditions comprised of a single initial denaturation at $94^{\circ} \mathrm{C}$ for $2 \mathrm{~min}$ followed by $30 \mathrm{cycles}$ at $90^{\circ} \mathrm{C}$ for $30 \mathrm{sec}$ (denaturation), $60^{\circ} \mathrm{C}$ for $30 \mathrm{sec}$ (annealing), $72^{\circ} \mathrm{C}$ for $30 \mathrm{sec}$ (extension), and a final extension step at $72^{\circ} \mathrm{C}$ for $5 \mathrm{~min}$. After the PCR amplification, the products were analyzed by electrophoresis using $1.5 \%$ agarose gel, which was stained with ethidium bromide. Then, the gels were visualized under ultraviolet light.

2.5. The Specificity and Sensitivity of the LAMP, PCR, $q L A M P$, and $q P C R$ Reactions. For the specificity testing, $500 \mathrm{ng} / \mu \mathrm{L}$ DNA templates of Salmonella typhimurium and non-Salmonella strains were subjected to all four assays?

The DNA sensitivity testing for all the bacterial strains was 10 -folds serial dilution from $5 \mu \mathrm{g} / \mu \mathrm{L}$ to $500 \mathrm{fg} / \mu \mathrm{L}$ for all four methods. The sensitivity test was triple duplication experiment.

2.6. Artificial Contamination of the Chicken Samples with Salmonella. For the experiment, uncooked chicken was collected from markets around Pathum Thani province in Thailand. Initially, $10 \mathrm{~g}$ of chicken breast samples was transferred to a sterile container and washed twice with $10 \mathrm{~mL}$ of sterile distilled water then washed once with $5 \%$ trisodium phosphate (to eliminate the background flora). Next, the samples were rinsed with $10 \mathrm{~mL}$ of sterile distilled water. After that, they were dried inside the hood under ultraviolet light for $3 \mathrm{~min}$ [14]. Then, the prepared samples were incubated in $10 \mathrm{~mL}$ of $10^{8} \mathrm{CFU}$ of $S$. typhi for $6 \mathrm{hr}$. and $1.5 \mathrm{~mL}$ of inoculated food was sampled at $0,1,2,4$, and $6 \mathrm{hr}$. time points. The solution was left to stand for $10 \mathrm{~min}$ to allow the particulate matter to settle at the bottom. Subsequently, the upper portion was collected and centrifuged at $10,000 \mathrm{~g}$ for $10 \mathrm{~min}$. The DNA was extracted from the pellet by following a simple boiling method [15]. Finally, the extracted DNA was ready to be used in the amplification.

2.7. The Detection of Salmonella in Chicken Samples Gathered from Local Markets. Thirty chicken samples (chicken breast) were collected from 10 local markets (three samples from one market) in Pathum Thani province, Thailand. All the samples were examined immediately after purchase then sent to a laboratory in an ice box. The DNA extracted from the samples $(10 \mathrm{~g})$ was used in the LAMP and PCR detection. The bacterial strains were incubated in LB (Luria-Bertani) agar plate at $37^{\circ} \mathrm{C}$ for $18 \mathrm{hr}$. Colonies were taken by sterile loopful and incubated in $\mathrm{LB}$ broth at $37^{\circ} \mathrm{C}$ for $18 \mathrm{hr}$. Then, such culture grown in LB broth was taken for the experiment.

\section{Results}

3.1. Specificity Test of LAMP and PCR. This results showed that the set of LAMP and PCR primers were specific-only Salmonella culture. The LAMP product and $198 \mathrm{bp}$ PCR product appeared in lane 1 shown in Figures 1(a) and 1(b).

3.2. Sensitivity Test of $L A M P, P C R, q L A M P$, and $q P C R$. To ascertain the detection limit of all four methods, 10-fold serial dilution of DNA template was used to compare all four assays. The detection limits of the LAMP assay were $50 \mathrm{pg}$, as 
TABLE 1: Primer sequences used for LAMP and PCR amplification.

\begin{tabular}{lrrr}
\hline Name & Sequence $\left(5^{\prime}-3^{\prime}\right)$ & Length $(\mathrm{bp})^{\text {Position }^{\mathrm{a}}}$ \\
\hline F3 & CGGCCCGATTTTCTCGG & 17 & $503-520$ \\
B3 & CGGCAATAGCGTCACCT & 17 & $665-682$ \\
FIP & GCGCGGCATCCGCATCAATA-TGCCCGGTAAACAGATGAGT & 40 & $573-592($ F1c) \\
& & $527-546($ F2) \\
BIP & GCGAACGGCGAAGCGTACTG-TCGCACCGTCAAAGGAAC & $593-612(\mathrm{~B} 1 \mathrm{c})$ \\
\end{tabular}

${ }^{a}$ The positions are numbered based on the coding sequence of the Salmonella invA gene (GenBank: M90846). F3 and B3 were used in PCR and qPCR reaction.
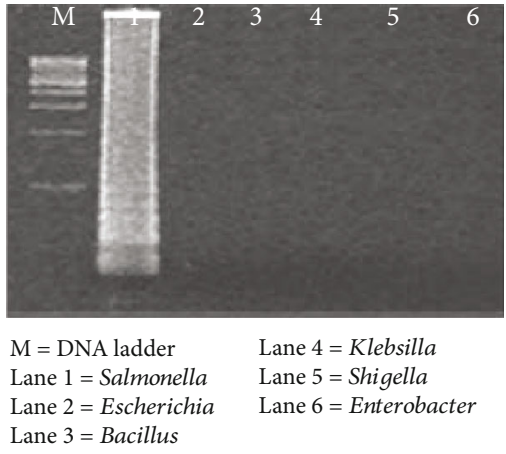

(a)

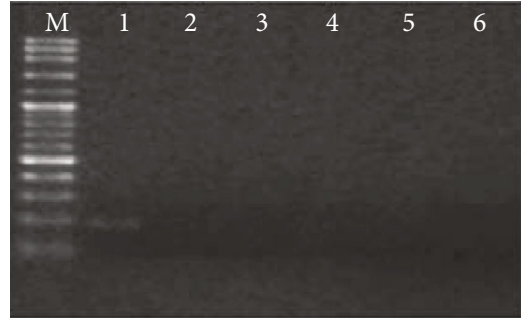

$\mathrm{M}=$ DNA ladder $\quad$ Lane $4=$ Klebsilla

Lane $1=$ Salmonella $\quad$ Lane $5=$ Shigella

Lane $2=$ Escherichia $\quad$ Lane $6=$ Enterobacter

Lane $3=$ Bacillus

(b)

Figure 1: The specificity test of LAMP and PCR technique. (a) The LAMP. (b) The PCR method. M: DNA marker; 1: Salmonella; 2: Escherichia; 3: Bacillus; 4: Klebsilla; 5: Shigella; and 6: Enterobacter.

shown in Figure 2(a). For the PCR reaction, $198 \mathrm{bp}$ amplicon was found in lanes 1, 2, and 3, as shown in Figure 2(b). Therefore, the sensitivity of the PCR method was $50 \mathrm{ng}$. For the qPCR method, the sensitivity was $5 \mathrm{ng}$ as shown in Figure 2(d). For the qLAMP method, the detection results are shown in Figure 2(c).

From Figure 2, the sensitivity of PCR, qPCR, LAMP, and qLAMP was $50 \mathrm{ng}, 5 \mathrm{ng}, 50 \mathrm{pg}$, and $500 \mathrm{fg}$, respectively.

3.3. The Detection of Salmonella in Spiked and Naturally Contaminated Chicken Samples. Within $2 \mathrm{hr}$. of the enrichment time, the LAMP, PCR, qLAMP, and qPCR methods had detected Salmonella DNA in the spiked chicken. A total of 30 chicken samples from 10 markets around Pathum Thani province were enriched for $2 \mathrm{hr}$. After the DNA extraction and amplification, only eight samples were positively detected by the conventional PCR method. The LAMP, qLAMP, and qPCR methods similarly detected Salmonella in all 30 chicken samples as shown in Table 2.

\section{Discussion}

The Salmonella invA gene was chosen for molecular detection with the PCR and qPCR methods because it has a broad specificity for more than 100 Salmonella serovars while exhibiting excellent exclusivity for non-Salmonella strains $[16,17]$.

The invA gene detection using the LAMP method was more rapid and sensitivity than the PCR method. The reac- tion time of LAMP was about 50 min while the reaction time of PCR was about $2.5 \mathrm{hr}$. The reaction time of LAMP was about $40 \mathrm{~min}$ faster than PCR. The limitation of LAMP (50 pg) reaction was 1,000 times higher than PCR (50 ng). The PCR efficiency of detection was 10 times better in qPCR (5ng).

When the qLAMP method was applied, the efficiency of the detection increased. $500 \mathrm{fg}$ of Salmonella DNA was detected using the qLAMP method. The sensitivity was 100 times higher than by conventional LAMP. The $50 \mathrm{ng}$ and $5 \mathrm{ng}$ of DNA were found to be approximately equivalent to $5 \times 10^{10}$ copies and $5 \times 10^{9}$ copies of the invA gene [18]. As Salmonella invA are single-copy genes they were converted to cell numbers $(1$ gene copy $=1$ cell) [18]. Therefore, $5 \times$ $10^{10}$ copies and $5 \times 10^{9}$ copies of invA gene were converted to $5 \times 10^{10}$ cells and $5 \times 10^{9}$ cells, respectively.

A single bacteria cell, which divides approximately every 30 minutes, can grow into a colony containing $10^{7}-10^{8}$ cells [19]. So, it means that the $5 \times 10^{10}$ cell of Salmonella is about 500 colonies or $500 \mathrm{CFU}$ and the $5 \times 10^{9}$ cells is about $50 \mathrm{col}-$ onies or $50 \mathrm{CFU}$ of Salmonella. For the conventional LAMP and qLAMP methods, 5 and $5 \times 10^{-2}$ CFU of Salmonella were detected. Chen et al. [13] also found that LAMP assay was more efficient than conventional PCR. Chen and his colleagues [3] use LAMP to detect Salmonella at $6.1 \times 10^{3}$ $\mathrm{CFU} / \mathrm{g}$ in spiked produce sample, whereas the limitation of conventional PCR for detecting Salmonella was $6.1 \times 10^{6}$ $\mathrm{CFU} / \mathrm{g}$ in spiked produce sample. So the sensitivity of PMA-LAMP was $10^{3}$ times higher than conventional PCR. 


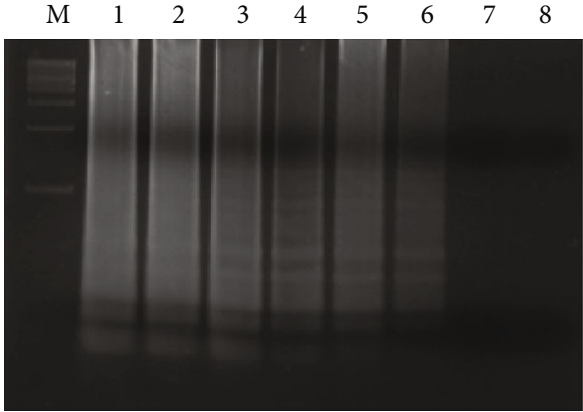

$\mathrm{M}=1 \mathrm{~kb}$ DNA ladder

Lane $5=500 \mathrm{pg}$

Lane $1=5 \mu \mathrm{g}$

Lane $2=500 \mathrm{ng}$

Lane $3=50 \mathrm{ng}$

Lane $4=5 \mathrm{ng}$

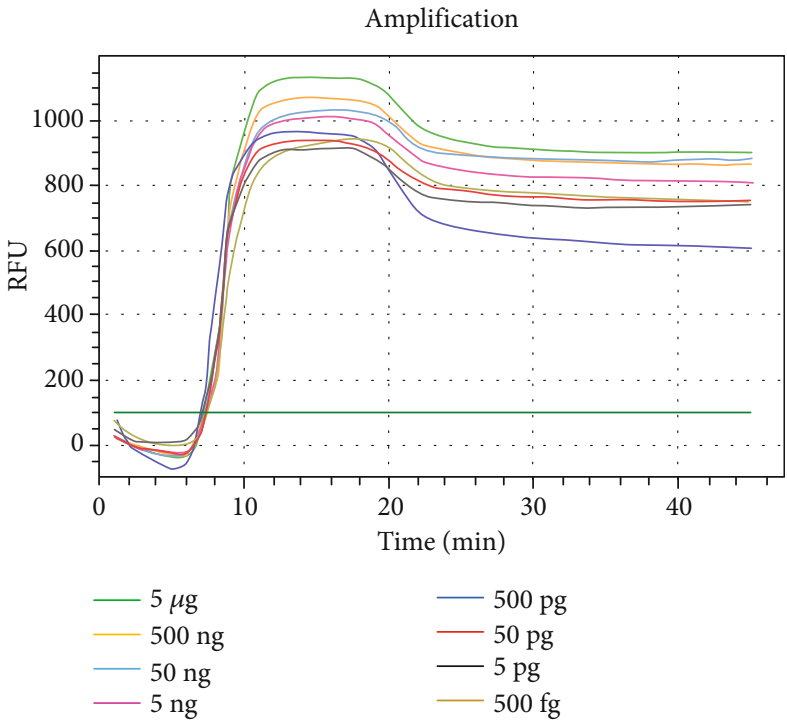

(c)

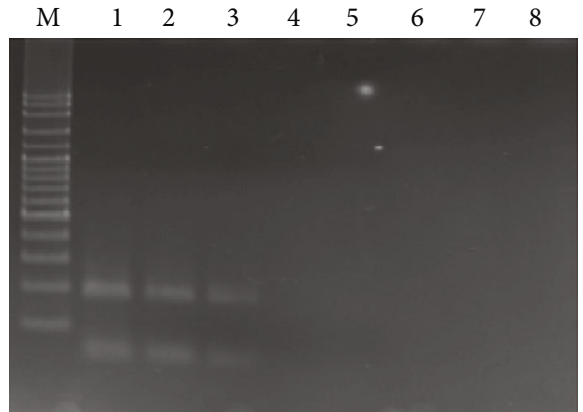

$\mathrm{M}=100$ bp DNA ladder $\quad$ Lane $5=500 \mathrm{pg}$

Lane $1=5 \mu \mathrm{g} \quad$ Lane $6=50 \mathrm{pg}$

Lane $2=500 \mathrm{ng} \quad$ Lane $7=5 \mathrm{pg}$

Lane $3=50 \mathrm{ng} \quad$ Lane $8=500 \mathrm{fg}$

Lane $4=5 \mathrm{ng}$

(b)

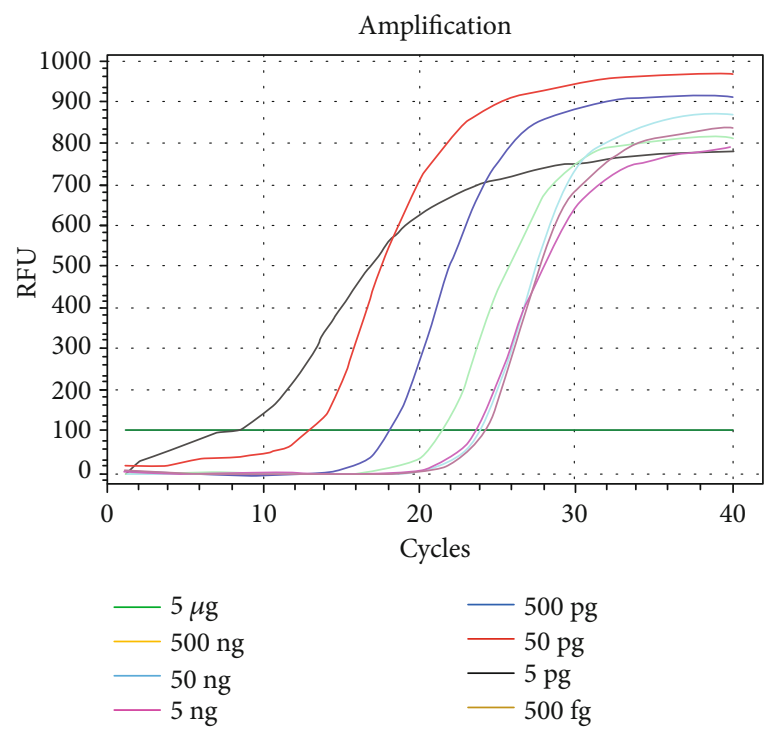

(d)

FIGURE 2: The sensitivity of all four methods in pure Salmonella culture by LAMP, PCR, qLAMP, and qPCR. (a) The LAMP method. M: 1 kb DNA marker; 1-8: 10-fold serial dilution of Salmonella DNA from $5 \mu$ g-500 fg. (b) The PCR method. M: 100 bp DNA marker; 1-8: 10-fold serial dilution of Salmonella DNA from $5 \mu \mathrm{g}-500 \mathrm{fg}$. (c) The qLAMP method. (D) The qPCR method.

TABLE 2: The number of Salmonella infected sample from 10 market by PCR, qPCR, LAMP, and qLAMP method.

\begin{tabular}{lcccc}
\hline Method & PCR & qPCR & LAMP & qLAMP \\
\hline Positive samples & $8 / 30$ & $30 / 30$ & $30 / 30$ & $30 / 30$ \\
\hline
\end{tabular}

Moreover, Chen et al. [13] compared TaqMan qPCR and LAMP in detecting Salmonella enterica serovar Enteritidis. Their results showed that there was a detection limit of four copies per reaction using both assays.

Additionally, another LAMP assay for Salmonella detection that targeted the phoP gene was able to detect $35 \mathrm{CFU}$ per reaction [20]. Srisawat and Panbangred [21] used the stn gene of Salmonella for LAMP amplification. The sensitivity was reported as $5 \mathrm{fg}$.

However, only a few studies have determined the qualitative capability of LAMP. One study investigating ammonia- oxidizing bacteria using LAMP found a good quantitative proficiency between $10^{4}$ and $10^{10}$ of DNA copies [22]. Another researcher investigated the quantitative capability of LAMP when combined with propidium monoazide sample treatment [14]; the detection limits were 3.4 to 34 viable Salmonella cells in pure culture and $6.1 \times 10^{3}$ to $6.1 \times 10^{4}$ CFU/g in spiked produce samples [14].

The LAMP, qLAMP, and qPCR methods detected Salmonella on all the chicken samples collected from the markets because the sensitivity of these methods is high. However, at least 100 colonies of Salmonella can cause the disease $[23,24]$. Even though all the chicken samples were found to be infected with Salmonella, the colony number was very low. This quantity of Salmonella does not cause the disease in humans.

Therefore, both LAMP and qLAMP have more dominants than PCR and qPCR in many aspects. They have more 
specificity (both LAMP used 2 pairs of primer, while as PCR used only one pair of primer), were more rapid (both LAMP used only 45-60 min to operate while both PCR used 1.5-2 hr. to operate), have more sensitivity, and have less complexity (LAMP technique do not require the complicated equipment).

Nevertheless, the disadvantage of LAMP is the use of indirect detection methods such as the turbidity of magnesium pyrophosphate, electrophoresis, and SYBR Green dye, which cannot differentiate between target products and nonspecific products, thereby leading to false positive [25]. So Wei and colleagues [26] used a molecular beacon to avoid the false positive by producing the fluorescence signals only when the molecular beacon binds to the target DNA. Moreover, the self-quenching and dequenching fluorogenic probes called fluorescence of loop primer upon self-dequenchingLAMP (FLOS-LAMP) [27] can reduce the nonspecific detection or false positive in the LAMP technique.

And even though LAMP has more sensitivity than both PCR and qPCR, our results show that the limitation of qLAMP (500 fg of Salmonella DNA) was 100 times higher than conventional LAMP (50 pg of Salmonella DNA). In terms of speed, the qLAMP can detected target DNA faster than PCR, qPCR, and LAMP and may be less susceptible to inhibitors than qPCR $[28,29]$. The qLAMP showed low false positive proportions than the magnesium pyrophosphate turbidimetric LAMP [30]. These reductions may be due to other factors besides amplification inhibitor [31].

\section{Conclusion}

This research found that PCR, LAMP, qLAMP, and qPCR were efficient methods of detecting Salmonella contamination in chicken. Especially, since both LAMP and qLAMP are more rapid, reliable, and robust for Salmonella detection in chicken samples and may be a valuable tool for routine testing. In addition, the qLAMP method is the most efficient in terms of sensitivity and rapidity.

\section{Data Availability}

The data used to support the findings of this study are available from the corresponding author upon request.

\section{Conflicts of Interest}

The authors declare that they have no conflicts of interest.

\section{Acknowledgments}

The authors would like to thank Assist. Prof. Dr. Laddawan Wasinpiyamongkol, Microbiology Unit, Faculty of Science, Rangsit University, Thailand, for providing bacteria in this study. The authors would like to sincerely thank Mr. Stewart Miller for critically correcting the English grammar. This work was supported by the Research Institute of Rangsit University, Thailand (Grant no. 9/2561).

\section{References}

[1] Q. Yang, K. J. Domesle, and B. Ge, "Loop-mediated isothermal amplification for Salmonella detection in food and feed: current applications and future directions," Pathogen and Disease, vol. 15, no. 6, pp. 309-331, 2018.

[2] M. Agbaje, R. H. Begum, M. A. Oyekunle, O. E. Ojo, and O. T. Adenubi, "Evolution of Salmonella nomenclature: a critical note," Folia Microbiology, vol. 56, no. 6, pp. 497-503, 2011.

[3] S. M. Pires, H. Vigre, P. Makela, and T. Hald, "Using outbreak data for source attribution of human salmonellosis and campylobacteriosis in Europe," Foodborne Pathogen Disease, vol. 7, no. 11, pp. 1351-1361, 2010.

[4] P. L. Petit and I. A. Wamola, "Typhoid fever: a review of its impact and diagnostic problems," East African Medical Journal, vol. 71, no. 3, pp. 183-188, 1994.

[5] E. Barbau-Piednoir, S. Bertrand, J. Mahillon, N. H. Roosens, and N. Botteldoorn, "SYBR ${ }^{\circledR}$ Green qPCR Salmonella detection system allowing discrimination at the genus, species and subspecies levels," Applied Microbiology and Biotechnology, vol. 97, no. 22, pp. 9811-9824, 2013.

[6] P. Balachandran, M. Friberg, V. Vanlandingham et al., "Rapid detection of Salmonella in pet food: design and evaluation of integrated methods based on real-time PCR detection," Journal of Food Protective Food, vol. 75, no. 2, pp. 347-352, 2012.

[7] C. M. CHENG, W. LIN, K. T. van, L. PHAN, N. N. TRAN, and D. FARMER, "Rapid detection of Salmonella in foods using real-time PCR," Journal of Food Protective, vol. 71, no. 12, pp. 2436-2441, 2008.

[8] B. Malorny, C. Löfström, M. Wagner, N. Krämer, and J. Hoorfar, "Enumeration of salmonella bacteria in food and feed samples by real-time PCR for quantitative microbial risk assessment," Journal of Applied and Environmental Microbiology, vol. 74, no. 5, pp. 1299-1304, 2008.

[9] N. M. Abdel-Aziz, "Detection of Salmonella species in chicken carcasses using genus specific primer belong to invA gene in Sohag city, Egypt," Veterinary World, vol. 9, no. 10, pp. 1125-1128, 2016.

[10] B. Webber, K. A. Borges, T. Q. Furian, N. N. Rizzo, E. C. Tondo, and L. R. D. Santos, "Detection of virulence genes in Salmonella Heidelberg isolated from chicken carcasses," Revista do Instituto de Medicina Tropical de São Paulo, vol. 61, 2019.

[11] T. Notomi, H. Okayama, H. Masubuchi, T. Yonekawa, K. Watanabe, and N. Amino, "Loop-mediated isothermal amplification of DNA," Nucleic Acids Research, vol. 28, no. 12 , pp. $63 \mathrm{e}-663,2000$.

[12] P. Kanchanaphum, S. Maneenin, and W. Chaiyana, “Analysis of pork meat using loop mediated isothermal amplification (LAMP) to confirm halal status," Internationl Journal of Bioscience, vol. 4, no. 9, pp. 62-68, 2014.

[13] S. Chen, F. Wang, J. C. Beaulieu, R. E. Stein, and B. Ge, "Rapid detection of viable salmonellae in produce by coupling propidium monoazide with loop-mediated isothermal amplification," Applied and Environmental Microbiology, vol. 77, no. 12, pp. 4008-4016, 2011.

[14] C. Techathuvanan, F. A. Draughon, and D. H. D'Souza, "Loopmediated isothermal amplification (LAMP) for the rapid and sensitive detection ofSalmonella typhimurium from pork," Journal of Food Science, vol. 75, no. 3, pp. M165-M172, 2010. 
[15] H. Zhang, L. Shi, L. Li et al., "Identification and characterization of class 1 integron resistance gene cassettes amongSalmonellaStrains isolated from healthy humans in China," Microbiology and Immunology, vol. 48, no. 9, pp. 639-645, 2004.

[16] N. González-Escalona, T. S. Hammack, M. Russell et al., "Detection of live Salmonella sp. cells in produce by a TaqMan-based quantitative reverse transcriptase real-time PCR targeting invA mRNA," Applied and Environmental Microbiology, vol. 75, no. 11, pp. 3714-3720, 2009.

[17] Y. Hara-Kudo, M. Yoshino, T. Kojima, and M. Ikedo, "Loopmediated isothermal amplification for the rapid detection of Salmonella," FEMS Microbiology Letters, vol. 253, no. 1, pp. 155-161, 2005.

[18] W. Ahmed, F. Huygens, A. Goonetilleke, and T. Gardner, "Real-time PCR detection of pathogenic microorganisms in roof-harvested rainwater in Southeast Queensland, Australia," Applied and Environmental Microbiology, vol. 74, no. 17, pp. 5490-5496, 2008.

[19] H. Lodish, A. Berk, S. L. Zipursky, P. Matsudaira, D. Baltimore, and J. Darnell, Molecular Cell Biology, W.H. Freeman, New York, NY, 4th edition, 2000.

[20] X. Li, S. Zhang, H. Zhang et al., "A loop-mediated isothermal amplification method targets the phoP gene for the detection of Salmonella in food samples," International Journal of Food Microbiology, vol. 133, no. 3, pp. 252-258, 2009.

[21] M. Srisawat and W. Panbangred, "Efficient and Specific Detection of Salmonella in Food Samples Using a stn- Based LoopMediated Isothermal Amplification Method," BioMed Research International, vol. 2015, Article ID 356401, 7 pages, 2015.

[22] Y. Aoi, M. Hosogai, and S. Tsuneda, "Real-time quantitative LAMP (loop-mediated isothermal amplification of DNA) as a simple method for monitoring ammonia-oxidizing bacteria," Journal of Biotechnology, vol. 125, no. 4, pp. 484-491, 2006.

[23] M. P. Doyle, "Pathogenic Escherichia coli, Yersinia enterocolitica, and Vibrio parahaemolyticus," Lancet, vol. 336, no. 8723, pp. 1111-1115, 1990.

[24] T. Mahami, W. Togby-Tetteh, D. I. Kottoh et al., "Microbial food safety risk to humans associated with poultry feed: the role of irradiation," International journal of food science, vol. 2019, Article ID 6915736, 7 pages, 2019.

[25] H. Patrick and J. A. H. Murry, "Lack of specificity associated with using molecular beacons in loop mediated amplification assays," BMC Biotechnology, vol. 19, no. 1, p. 55, 2019.

[26] W. Liu, S. Huang, N. Liu et al., "Establishment of an accurate and fast detection method using molecular beacons in loopmediated isothermal amplification assay," Scientific Reports, vol. 7, no. 1, 2017.

[27] V. J. Gadkar, D. M. Goldfarb, S. Gantt, and P. A. G. Tilley, "Real-time detection and monitoring of loop mediated amplification (LAMP) reaction using self-quenching and dequenching fluorogenic probes," Scientific Reports, vol. 8, no. 1, p. 5548, 2018.

[28] H. Tani, T. Teramura, K. Adachi et al., "Technique for quantitative detection of specific DNA sequences using alternately binding quenching probe competitive assay combined with loop-mediated isothermal amplification," Analytical Chemistry, vol. 79, no. 15, pp. 5608-5613, 2007.

[29] G. J. Nixon, H. F. Svenstrup, C. E. Donald et al., “A novel approach for evaluating the performance of real time quantita- tive loop-mediated isothermal amplification-based methods," Biomolecular Detection and Quantification, vol. 2, pp. 4-10, 2014.

[30] L. D. Thiessen, T. M. Neill, and W. F. Mahaffee, "Development of a grower-conducted inoculum detection assay for management of grape powdery mildew," Plant Pathology, vol. 65, no. 2, pp. 238-249, 2016.

[31] L. D. Thiessen, T. M. Neill, and W. F. Mahaffee, "Development of a quantitative loop-mediated isothermal amplification assay for the field detection ofErysiphe necator," PeerJ, vol. 6, p. e4639, 2018. 